\title{
ASAS-ASAS UMUM PERADILAN YANG BAIK MENURUT KONSEPSI MAHKAMAH AGUNG REPUBLIK INDONESIA
}

\author{
BUDI HARYOKO \\ Budiharyoko64@gmail.com \\ 191003600523 \\ UNIVERSITAS EKASAKTI PADANG
}

\section{A. PENDAHULUAN}

Hukum acara khususnya hukum pembuktian dan penemuan hukum, relatif belum lama mendapat perhatian dari para sarjana hukum. Selama ini hukum acara boleh dikatakan setengahnyadiabaikan atau diremehkan oleh para sarjana hukum. Hal ini terbukti dari perhatian mereka antara lain pada pernbuktian dan penemuan hukum, kurang atau skeptis, serta dari kenyataan bahwa padaumumnya mereka yang menulis tentang hukum hanya tertarik pada masalah tentang hukum materiil saja: tentang hukum perdata materiil, hukum pidana materiil dan sebagainya. Buku-buku tentangpembuktian dan penemuan hukum boleh dikatakan masih jarang dibandingkan dengan buku-buku tentang hukum perdata materiil. Pandangan tersebut diatas, bahwa para sapna hukum lebih tertarik pada hukum materiil, dianut tidak lepas dari pengaruh sistem pendidikan hukum diwaktu yang lampau, karena setiap pendidikan hukum diwaktu yang lampau, terutama di Belanda yang berpengaruh di lndonesia, dipusatkan atau mengacu dan harus msngacu pada hukum materiil dan dengan sendirinya harus menitik beratkan pada problematik hukurn materiil, pada hukum sebagai sumber 
masalah. kearah itulah calon sarjana hukum diwaktu yang lampau dididik. Oleh karena itu perhatian para sarjana hukum lebih banyak ditujukan pada hukum materiil.

Di samping itu tidak asing lagi ungkapan terkenal diwaktu yang lampau bahwa hakim adalah "la bouche de la to" seagai pengaruh aliran legisme, yang berarti bahwa hakim hanya sekedar corong dariundang-undang saja' Pandangan pada waktu itu tidak mengakui fungsi hakim dan tanggung jawabnya daram rnenentukan ataumenetapkan apa yang terjadi. Tugas hakim hanyalah mekhanis, seikedar menerapkan bunyi undang-undang dan tidak melakukan penemuan hukum. Dengan demikian hukum acaranya, terutama hukum pembuktian dan penemuan hukum tidak beberapa mendapat perhatian, sehingga perhatiannya dicurahkan pada hukum materiil perdata.

Kemahiran hukum, pemecahan masalah-masalah hukum(legal problem solving) penemuan hukum dan sebagainya, belum lama ini mulai diajarkan namun orientasinya sebagian besar para sarjana hukum masih diarahkan kepada hukum materiil. Tulisan-tulisan masih banyak yang berhubungan dengan hukum perdata materiil.

Berdasarkan apa yang telah dikemukakan diatas maka dirasa perlu bagi para sarjana hukum untuk murai memusatkan perhatiannya juga kepada masarahmasalah hukum acara, penemuan hukum dan pembuktian. Hukum perdata materiil tidak rnungkin dilepaskan sama sekali dari hukum acara perdata. Hukum perdata materiil harus dilaksanakan dan ditegakkan. Makin maju manusia' makin 
berkembang kepentingannya makin banyak pula terjadi sengketa' untuk itu dibutuhkan hukum acara perdata.

Dalam titeratur hukum acara perdata modern hukum acara beracara (actienrecht),hukum perdata meliputi hukum pembuktian(bewijsrecht), hukum penyitaan (beslagrecht), penemuan hukum(rechtsvinding) dan hukum eksekusi (executiere) Bukan berarti bahwa masing-masing bagian itu merupakan cabang ilmu yang berdiri sendiri-sendiri. Tidak dimaksudkan dalam tulisan singkat ini untuk menguraikan tentang keseluruhan hukum acara perdata.

Adapun rumusan masalah adalah : Apa sajakah asas-asas umum suatu peradilan yang baik menurut konsepsi Mahkamah Agung Repulik Indonesia ?

Adapun tujuan pembahasan makalah ini adalah untuk mengetahui asas-asas umum suatu peradilan yang baik menurut konsepsi Mahkamah Agung Repulik Indonesia.

\section{B. PEMBAHASAN}

Terlebih dahulu akan dijelaskan apa yang dimaksudkan dengan peradilan (judicature) Yang dimaksudkan dengan Peradilan adalah pelaksanaan hukum dalam hal ada tuntutan hak yang konkret, fungsi mana dijalankan oleh suatu badan yang berdiri sendiri dan diadakan oleh negara serta bebas dari pengaruh apa atau siapapun dengan cara memberikan putusan yang bersifat mengikat dan bertujuan mencegah eigenrichting. "Pelaksanaan hukum dalam hal ada tuntutan hak yang konkret" berarti bahwa tuntutan hak ini nyata-nyata ada dan diajukan ke pengadilan, suatu badan yang diadakan oleh negara, yang bebas dari pengaruh 
yudisiil maupun extra-yudisiil. pelaksanaan hukum itu terjadi dengan suatu putusan, yang bersifat mengikat para pihak, definif dan tuntas. Tuntutan hak yang dimaksudkan adalah tindakan untuk memperoleh perlindungan hukum tanpa bertindak menghakimi sendiri (eigenrichting).

Beracara perdata bersifat sukarela yang berarti bahwa apakah seseorang akan mengajukan tuntutan hak atau tidak itu bersifat sukarela' Terserah pada seorang yang dirugikan oleh orang lain misalnya apakah ia akan mengajukan tuntutan hak (menggugat) atau tidak' Pada dasarnya setiap orang dapat mengajukan gugatan atau tuntutan hak apabila ia mempunyai kepentingan hukum, yang diungkapkan dengan adagium point d'interet, point d'action. Jadi sepenuhnya terserah kepada yang mempunyai kepentingan hukum untuk menggugat atau tidak. Dengan demikian hakim bersikap menunggu atau pasif sampai ada perkara diajukan atau dibagikan (oleh Ketua) kepadanya. Tidak ada penggugat (gugatan) maka tidak ada hakim (wo kein Klager ist, ist kein Richter). Jadi hakim tidak pergi ke pelosok-pelosok menawarkan diri untuk memeriksa dan mengadili perkara kalau-kalau ada perkara. Adagium lain, yang

Berhubungan dengan asas "hakim pasif", tersebut ialah nemo judexsine actore,yangberartitiadahakimmakatiadatuntutan,yang diartikan juga: tiada tuntutan maka tiada hakim. Jadi hakim bersikap menunggu datangnya tuntutan atau gugatan, tidak bertindok secara ex officio (iudex ne procedat ex officio) tahun 1970 singkatnya berbunyi : tugas pokok badan-badan peradilanmenerimasetiap perkara yang diajukan kepadanya. 
Terbuka sidang umum menunjukkan bahwa pemeriksaan dimuka sidang berlangsung transparan, tidak ada yang ditutup-tutupi, tidak ada yang dirahasiakan, disembunyikan dari umum Asas ini tercantum dalam pasal 17 ayat 1 UU no 14 tahun 1970 yang berbunyi: sidang pemeriksaan pengadilan adatah terbuka untuk umum, kecuali apabila Undang-undang menentukan lain. Sering diartikan asas terbukanya sidang ini sebagai social controle, kontrol masyarakat dalam jalannya sidang. Social controle tidak berarti bahwa masyarakat boleh menegur atau mengadakan koreksi terhadap hakim di persidangan. Kehadiran masyarakat (pengunjung) Di persidangan sudah berarti kontrol terhadap jalannya persidangan.

Sekalipun asasnya adalah terbukanya sidang untuk umum,akan tetapi sebagaimana asas itu memberi peluang akan pengecualian-pengecualian atau penyimpangan-penyimpangan, maka disinipun dimungkinkan adanya sidang tertutup untuk umum. lni bukan berarti bahwa pemeriksaannya berlangsung tidak transparan, akan tetapi ini justru dilakukan untuk melindungi kepentingan para pihak. Pemeriksaan pengadilan dengan pintu tertutup misalnya dalam perceraian atau apabila menyangkut anak-anak.

Karena pencari keadilan atau justiciabele mengajukan tuntutan ke pengadilan itu bertujuan untuk memperoleh perlindungan hukum,maka hakim tidak boleh menolak memeriksa dan mengadili perkara dengan dalih apapun, bahkan dengan dalih hukumnya tidak ada sekalipun. Hakim wajib memeriksa dan mengadili perkara (pas. 14 ayat 1 UU 14 tahun 1970). Tujuan beracara di pengadilan adalah sampai pada suatu putusan. Hakim wajib menggali nilai-nilai 
hukum yang ada didalam masyarakat (pas.27 UU no.14 th 1970). Disini hakim berkesempatan untuk melakukan penemuan hukum, walaupun penemuan hukum itu tidak hanya dilakukan kalau hukumnya tidakada. \$ebagai salah satu asas ini ialah banyaknya undang-undang sekarang ini yang memuat ketentuan bahwa peraksanaan beberapa pasar di dalamnya dikeluarkannya peraturan pemerintah (peraturan organik), sehingga banyak hakim yang tidak berani memutus perkara yang peraturan pemerintah sebagai peraturan pelaksanaannya belum diterbitkan. Hakim menunggu sampai dikeluarkan peraturan pemerintah yang bersangkutan, tetapi tidak kunjung datang. Disini diperlukan Penguasaan sistem hukum dan pengetahuan tentang penemuan hukum serta keberanian dari hakim untuk mengadakan trobosan-trobosan hukum. Mengadakan trobosan hukurn tidak berarti asal berani tanpa mengingat keseluruhan sistem hukum. Sistem hokum harus didahulukan. Cara berfikir mendasar pada system huku semata-mata disebut system oriented thinking.kalau sistemnya tidak member jawaban yang memuaskan barulah ada kebebasab bagi hakim untuk menyimpang dari system dengan memperhatikan permasalahan. Ini yang disebut dengan problem oriented thinking. Terobosan hokum jangan sampai mengarah pada contra legem( melanggar undang-undang).

Hokum itu sudah ada, hanya masih perlu digali kepermukaan. Bahwa menurut paul scholten hukum itu tidak hanya terdapat dalam peraturan-peraturan atau hukum tidak tertulis saja, tetapi terdapa tpada perilaku manusia.

Kalau mengingat keadaan hukum kita dewasa ini kita wajib prihatin. Betapa tidak. Kita semua tahu bahwa menurt UU no.14 tahun 1970 hakim itu ada 
dibawah dua atap yaitu dibawah Mahkamah Agung dan Departemen Kehakiman (yang berubah nama menjadi departemen kehakiman dan perundang-undangan kemudian menjadi departemen kehakiman dan Ham). Dengan dikeluarkannya UU no.35 tahun 1999 hakim tidak lagi dibawah dua atap, tetapi dibawah satu atap, yaitu Departemen Kehakiman dan Ham. ltu baru akan berlangsung lima tahun sesudah diundangkannya UU no.35 tahun 1999. Kemudian dikeluarkan UU no.14 tahun 2002 tentang Pengadilan Pajak yang antara lain menentukan bahwa hakim Pengadilan Pajak secara oganisatoris, administratif dan finansiil ada dibawah Departemen Keuangan. Apakah ini tidak bertentangan dengan UU no.35 tahun 1999 (contra legem) yang menempatkan hakim dari 4 lingkungan peradilan di bawah Mahkarnah Agung? Belum lagi didalam UU no.14 tahun 2002 itu dengan menyebut pasal 24 UUD dalam konsideransnya, menentukan bahwa Pengadilan Pajak itu ada langsung dibawah Mahkamah Agung, yang berarti bahwa sekarang ini ada 5 lingkungan peradilan, sedangkan menurut pasal 24 ayat 2 UUD (Amandemen ketiga) dibawah Mahkamah Agung hanya ada 4 lingkungan peradilan. lni sudah merusak sistem hukum lndonesia.

Dalam memeriksa perkara hakim harus bersikap tut wuri, mengikuti dari belakang.Tutwuri tidak berarti bahwa hakim pasif memimpin sidang. Hakim harus aktif memimpin sidang dengan membantu para pencari keadidlan dan berusaha sekeras-kerasnya mengatasi segala hambatan dan rintangan untuk dapat tercapainya peradilan yang sederhana, cepat dan biaya ringan.(pas.5 ayat 2) Tut wuri berarti bahwa hakim terikat pada peristiwa yang diajukan oleh para pihak (secundum allegata iudicare). Hakim tidak boleh mengabulkan lebih dari yang 
dituntut (pas. 178 ayat $3 \mathrm{HIR}$, ne ultra petita). Hakim perdata tidak memberi keputusan kepada apa yang tidak dituntut (ultra petita non cognoscitur). Dari pasal 178 ayat 3 HIR dapat disimpulkan bahwa kepentingan para pihak merupakan salah satu surnber hukum disamping undang-undang, kebias aan,yurisprudensi, doktrin dan perjanjian internasional.

Berhubung dengan pasal 178 ayat 3 HIR ini sering dipertanyakan apakah hakim masih terikat pada pasal 178 ayat 3 HIR tersebut kalau ia menghadapi petitum primair dan petitum subsidiair yang pada umumnya berbunyi "mohon putusan seadil-adilnya" Disini hakim dituntut kearifannya.

Pada dasamya asas hukum dasar daram acara perdata adalah kesamaan: suum cuiqe tibuerc, yang berarti setiap orang mendapat haknya atau to each his own. Lebih populer lagi ungkapan equatity before the law. Lebih ranjut ini berarti bahwa setiap orang harus diperlakukan sama. Di dalam hukum acara perdata asas ini lebih dikenal dengan audie et alteram partem (pas.125, $126 \mathrm{HIR}$ ). Kedua belah pihak dipersidangan harus diperlakukan sama dalam arti didengar bersama. Misalnya kalau hanya penggugat saja yang datang, sedangkan tergugat tidak hadir, maka hakim tidak boreh mendengar penggugat tanpa hadirnya tergugat.

Dalam hal pembuktian dikenal asas bahwa barangsiapa mengatakan mempunyai suatu hak atau menyebutkan suatu peristiwa untuk meneguhkan haknya atau untuk menyangkal hak orang lain maka dialah yang diharuskan membuktikan adanya hak atau peristiwa itu (actori incumbit probatio): pasal 163 HIR, 1865 KUHPer. Asas ini berhubungan dengan asas lain yang berbunyi: membuktikan suatu negatie itu tidak mungkin atau setidak-tidaknya sukar 
(negativa nen sunt probanda).Permasalahan pokok dalam hal pembuktian ialah pembagian beban pembuktian. Dalam hal ini tidak ada peraturan atau pedomannya. Hanya ada yurisprudensi Mahkamah Agung yang mengatakan bahwa pihak yang paling sedikit dirugikanlah yang harus membuktikan.

Kecuali sebagai pertanggungan jawab hakim kepada masyarakat dan para pihak serta kepada pengadilan yang lebih tinggi, juga untuk menunjukkan transparansi dan objektivitas pemeriksaan maka putusan harus disertai alasanalasan atau pertimbangan- pertimbangan (konsiderans) mengapa hakim sampai pada putusannya itu (pas.184 ayat 1, 319 HIR). Jadi putusannya itu tidak bersifat langsung, sehingga dapat diketahui pertimbangan- pertimbangan apa yang menyebabkan hakim sampai pada putusannya itu. Kalau suatu putusan tidak disertai alasan-alasan, rnaka hal itu merupakan alasan untuk dibatalkan ditingkat kasasi (MA 22 Juli 1970). Hal lini bukan berarti bahwa hakim merupakan "la bouche de la societe".

Telah dikemukakan bahwa tujuan berperkara pada dasarnya adalah sampai pgda putusan. Tidak akan suatu proses pemeriksaan perkara itu berhenti di jalan, tidak dilanjutkan sampai pada putusan, apapun bunyi putusan itu: ditolak, dikabulkan atau tidak diterima. Kalau tidak terbuktipun putusannya akan dijatuhkan juga. Suatu putuan itu harus objektif, definitif dan tuntas. Objektif disini berarti tidak memihak kepada salah satu pihak. Bahwasanya salah satu pihak diputus menang bukan berarti memihak, tetapi memang itulah yang terbukti. .Definitif berarti bahwa putusan itu sudah pasti. lsinya tidak menimbulkan pertanyaan atau keraguan. Timbul pertanyaan dengan adanya 
putusan dari Pengadidlan Niaga yang memungkinkan adanya putusan yang memuat "dissenting opinion", yaitu pendapat hakim yang berbeda dengan hakim anggota yang lain yang dimuat pula dalam putusan. Perlu difahami bahwa lembaga dissenting opinion berasal dari sistem hukum Anglosaks, sehingga perlu dipertanyakan apakah sudah sesuai dengan sistem hukum kita bahwa putusan itu harus definitif. Ruftusan harus tuntas, selesai, sehingga tidak menimbulkan persoalan atau perkara baru atau tidak dapat dieksekusi.

\section{ASAS-ASAS UMUM PERADILAN YANG BAIK}

\section{Penerapan Asas retroaktif}

Dari sisi pengetahuan hukum, asas retroaktif dapat diberlakukan secara rigid dan darurat limitatif, artinya apabila negara dalam keadaan darurat (abnormal) maka pemerintah harus menerapkan prinsip-prinsip hukum darurat (abnormaal recht), karena itu penempatan asas ini hanya bersifat temporer, jika jika kondisi negara sudah normal maka asas retroaktif tidak diberlakukan lagi. Dalam penerapan asas retroaktif harus memerhatikan prinsip-prinsip hukum universal sehingga tidak terkontaminasi dengan unsur-unsur yang dapat dikategorikan sebagai abuse of power.

\section{Asas Persamaan di Mata Hukum}

Setiap orang mempunyai kedudukan yang sama di depan hukum. Ini adalah salah satu asas peradilan yang merdeka dan fair yang berlaku secara universal. Asas ini merupakan larangan terhadap perlakuan diskriminatif baik berdasarkan suku, agama, kebangsaan, mapun 
berdasarkan kedudukan atau jabatan. Aparat peradilan tidak diperbolehkan berlaku diskriminatif terhadap siapa pun yang mencari kedilan.

\section{Asas Persidangan yang terbuka untuk umum}

Asas persidangan yang terbuka untuk umum sangat menunjang kemandirian kekuasaan kehakiman. Asas persidangan yang terbuka untuk umum bertujuan untuk menjamin para pencari keadilan untuk mendapatkan akses informasi terhadap jalannya persidangan. Untuk itu bukan berarti setiap orang harus datang ke persidangan untuk mengetahui jalannya persidangan, tetapi masyarakat dapat memperolehnya dari media massa dan sebagainya. Karena itu pengadilan harusmenjamin akses media massa meliput persidangan. Asas ini memberikan kontrol public terhadap putusan-putusan pengadilan

\section{Asas Perlindungan korban dan saksi}

Asas ini terkadang terabaikan. Perlindungan saksi dan korban adalah merupakan persoalan penting dalam setiap kasus kejahatan. Urgensi atas perlindungan saksi dan korban ini adalah karena jenis kejahatan yang terjadi dan pelaku yang selalu mempunyai kekuatan dan sumber daya yang luar biasa untuk melakukan upaya-upaya intimidasi dan tekanan kepada korban maupun saksi. Internasional Criminal Court, secara lengkap mengatur tentang perlindungan korban dan saksi dan 
menyaratkan adanya suatu unit khusus untuk menangani persoalan saksi dan korban.

\section{PENUTUP}

Beracara perdata bersifat sukarela yang berarti bahwa apakah seseorang akan mengajukan tuntutan hak atau tidak itu bersifat sukarela' Terserah pada seorang yang dirugikan oleh orang lain misalnya apakah ia akan mengajukan tuntutan hak atau tidak' Pada dasarnya setiap orang dapat mengajukan gugatan atau tuntutan hak apabila ia mempunyai kepentingan hukum, yang diungkapkan dengan adagium point d'interet,point d'action . Jadi sepenuhnya terserah kepada yang mempunyai kepentingan hukum untuk menggugat atau tidak. Hakim wajib menggali nilai-nilai hukum yang ada didalam masyarakat . \$ebagai salah satu asas ini ialah banyaknya undang-undang sekarang ini yang memuat ketentuan bahwa peraksanaan beberapa pasar di dalamnya dikeluarkannya peraturan pemerintah, sehingga banyak hakim yang tidak berani memutus perkara yang peraturan pemerintah sebagai peraturan pelaksanaannya belum diterbitkan.

Hakim menunggu sampai dikeluarkan peraturan pemerintah yang bersangkutan, tetapi tidak kunjung datang. Cara berfikir mendasar pada system huku semata-mata disebut system oriented thinking.kalau sistemnya tidak member jawaban yang memuaskan barulah ada kebebasab bagi hakim untuk menyimpang dari system dengan memperhatikan permasalahan. Ini yang disebut dengan problem oriented thinking. 14 tahun 2002 tentang Pengadilan Pajak yang antara 
lain menentukan bahwa hakim Pengadilan Pajak secara oganisatoris, administratif dan finansiil ada dibawah Departemen Keuangan.

Hakim perdata tidak memberi keputusan kepada apa yang tidak dituntut. Berhubung dengan pasal 178 ayat 3 HIR ini sering dipertanyakan apakah hakim masih terikat pada pasal 178 ayat 3 HIR tersebut kalau ia menghadapi petitum primair dan petitum subsidiair yang pada umumnya berbunyi «mohon putusan seadil-adilnya» Disini hakim dituntut kearifannya. Misalnya kalau hanya penggugat saja yang datang, sedangkan tergugat tidak hadir, maka hakim tidak boreh mendengar penggugat tanpa hadirnya tergugat. Hanya ada yurisprudensi Mahkamah Agung yang mengatakan bahwa pihak yang paling sedikit dirugikanlah yang harus membuktikan.

Kecuali sebagai pertanggungan jawab hakim kepada masyarakat dan para pihak serta kepada pengadilan yang lebih tinggi, juga untuk menunjukkan transparansi dan objektivitas pemeriksaan maka putusan harus disertai alasanalasan atau pertimbangan- pertimbangan mengapa hakim sampai pada putusannya itu . Jadi putusannya itu tidak bersifat langsung, sehingga dapat diketahui pertimbangan- pertimbangan apa yang menyebabkan hakim sampai pada putusannya itu. Bahwasanya salah satu pihak diputus menang bukan berarti memihak, tetapi memang itulah yang terbukti. Timbul pertanyaan dengan adanya putusan dari Pengadidlan Niaga yang memungkinkan adanya putusan yang memuat, yaitu pendapat hakim yang berbeda dengan hakim anggota yang lain yang dimuat pula dalam putusan. 
Bersadarkan pada uraian diatas dapat disimpulkan bahwa persidangan yang ada saat ini belum memenuhi standar persidangan yang adil dan tidak memihak, seperti tidak terpenuhinya asas persamaan di depan hukum, tidak terpenuhinya asas peradilan yang terbuka untuk umum, dan tidak adanya perlindungan yang memadai terhadap saksi dan korban. Tidak terpenuhinya asas-asas kekuasaan kehakiman yang merdeka. 


\section{DAFTAR PUSTAKA}

Darmini Roza dan Laurensius Arliman S Peran Pemerintah Daerah Di Dalam Melindungi Hak Anak Di Indonesia, Masalah-Masalah Hukum, Volume 47, Nomor 1, 2018.

Laurensius Arliman S, Komnas HAM dan Perlindungan Anak Pelaku Tindak Pidana, Deepublish, Yogyakarta, 2015.

Laurensius Arliman S, Penguatan Perlindungan Anak Dari Tindakan Human Trafficking Di Daerah Perbatasan Indonesia, Jurnal Selat, Volume 4, Nomor 1, 2016.

Laurensius Arliman S, Problematika Dan Solusi Pemenuhan Perlindungan Hak Anak Sebagai Tersangka Tindak Pidana Di Satlantas Polresta Pariaman, Justicia Islamica, Volume 13, Nomor 2, 2016.

Laurensius Arliman S, Pelaksanaan Perlindungan Anak Yang Tereksploitasi Secara Ekonomi Oleh Pemerintah Kota Padang, Veritas et Justitia, Volume 2, Nomor 1, 2016.

Laurensius Arliman S, Kedudukan Ketetapan MPR Dalam Hierarki Peraturan Perundang-Undangan Di Indonesia, Lex Jurnalica, Volume 13, Nomor 3, 2016.

Laurensius Arliman S, Komnas Perempuan Sebagai State Auxialiary Bodies Dalam Penegakan Ham Perempuan Indonesia, Justicia Islamica, Volume 14, Nomor 2, 2017.

Laurensius Arliman S, Peranan Pers Untuk Mewujudkan Perlindungan Anak Berkelanjutan Di Indonesia, Jurnal Ilmu Hukum Tambun Bungai, Volume 2, Nomor 2, 2017.

Laurensius Arliman S, Mewujudkan Penegakan Hukum Yang Baik Untuk Mewujudkan Indonesia Sebagai Negara Hukum, Jurnal Hukum Doctrinal, Volume 2, Nomor 2, 2017. 
Laurensius Arliman S, Participation Non-Governmental Organization In Protecting Child Rights In The Area Of Social Conflict, The 1st Ushuluddin and Islamic Thought International Conference (Usicon), Volume 1, 2017.

Laurensius Arliman S, Partisipasi Masyarakat Dalam Pembentukan Perundang-Undangan Untuk Mewujudkan Negara Kesejahteraan Indonesia, Jurnal Politik Pemerintahan Dharma Praja, Volume 10, Nomor 1, 2017, https://doi.org/10.33701/jppdp.v10i1.379.

Laurensius Arliman S, Peran Komisi Perlindungan Anak Indonesia Untuk Mewujudkan Perlindungan Anak, Jurnal Respublica Volume 17, Nomor 2, 2018.

Laurensius Arliman S, Menjerat Pelaku Penyuruh Pengrusakan Barang Milik Orang Lain Dengan Mempertimbangkan Asas Fungsi Sosial, Jurnal Gagasan Hukum, Volume 1, Nomor 1, 2019.

Laurensius Arliman S, Ilmu Perundang-Undangan Yang Baik Untuk Negara Indonesia, Deepublish, Yogyakarta, 2019.

Laurensius Arliman S, Isdal Veri, Gustiwarni, Elfitrayenti, Ade Sakurawati, Yasri, Pengaruh Karakteristik Individu, Perlindungan Hak Perempuan Terhadap Kualitas Pelayanan Komnas Perempuan Dengan Kompetensi Sumber Daya Manusia Sebagai Variabel Mediasi, Jurnal Menara Ekonomi: Penelitian dan Kajian Ilmiah Bidang Ekonomi, Volume 6, Nomor 2, 2020.

Laurensius Arliman S, Pendidikan Kewarganegaraan, Deepublish, Yogyakarta, 2020.

Laurensius Arliman S, Makna Keuangan Negara Dalam Pasal Pasal 23 E UndangUndang Dasar 1945, Jurnal Lex Librum, Volume 6, Nomor 2 Juni 2020, http://dx.doi.org/10.46839/lijih.v6i2.151.

Laurensius Arliman S, Kedudukan Lembaga Negara Independen Di Indonesia Untuk Mencapai Tujuan Negara Hukum, Kertha Semaya Journal Ilmu Hukum, Volume 8, Nomor 7, 2020.

Laurensius Arliman S, Pelaksanaan Assesment Oleh Polres Kepulauan Mentawai Sebagai Bentuk Pelaksanaan Rehabilitasi Bagi Pecandu Dan Korban Penyalahgunaan Narkotika, Jurnal Muhakkamah, Volume 5, Nomor 1, 2020. 
Laurensius Arliman S, Aswandi Aswandi, Firgi Nurdiansyah, Laxmy Defilah, Nova Sari Yudistia, Ni Putu Eka, Viona Putri, Zakia Zakia, Ernita Arief, Prinsip, Mekanisme Dan Bentuk Pelayanan Informasi Kepada Publik Oleh Direktorat Jenderal Pajak, Volume 17, No Nomor, 2020.

Larensius Arliman S, Koordinasi PT. Pegadaian (Persero) Dengan Direktorat Reserse Narkoba Polda Sumbar Dalam Penimbangan Barang Bukti Penyalahgunaan Narkotika, UIR Law Review, Volume 4, Nomor 2, 2020, https://doi.org/10.25299/uirlrev.2020.vol4(1).3779.

Laurensius Arliman S, Tantangan Pendidikan Kewarganegaraan Pada Revolusi 4.0, Ensiklopedia Sosial Review, Volume 2, Nomor 3, 2020.

Muhammad Afif dan Laurensius Arliman S, Protection Of Children's Rights Of The Islamic And Constitutional Law Perspective Of The Republic Of Indonesia, Proceeding: Internasional Conference On Humanity, Law And Sharia (Ichlash), Volume 1, Nomor 2, 2020.

Otong Rosadi danLaurensius Arliman S, Urgensi Pengaturan Badan Pembinaan Idelogi Pancasila Berdasarkan Undang-Undang Sebagai State Auxiliary Bodies yang Merawat Pancasila dalam Perspektif Hak Asasi Manusia, Prosiding Konferensi Nasional Hak Asasi Manusia, Kebudayaan dan Tujuan Pembangunan Berkelanjutan Indonesia pada Masa Pandemi Covid-19: Tantangan untuk Keilmuan Hukum dan Sosial Volume 1, Universitas Pancasila, Jakarta, 2020. 